\title{
Peirce and Iconology
}

Habitus, Embodiment, and the Analogy between Philosophy and Architecture

\section{Tullio Viola}

\section{(2) OpenEdition}

\section{Journals}

Electronic version

URL: http://journals.openedition.org/ejpap/764

DOI: $10.4000 /$ ejpap.764

ISSN: 2036-4091

\section{Publisher}

Associazione Pragma

\section{Electronic reference}

Tullio Viola, «Peirce and Iconology », European Journal of Pragmatism and American Philosophy [Online], IV - 1 | 2012, Online since 20 July 2017, connection on 21 April 2019. URL : http://

journals.openedition.org/ejpap/764; DOI : 10.4000/ejpap.764

This text was automatically generated on 21 April 2019.

\section{(c) $(1)$}

Author retains copyright and grants the European Journal of Pragmatism and American Philosophy right of first publication with the work simultaneously licensed under a Creative Commons AttributionNonCommercial-NoDerivatives 4.0 International License. 


\section{Peirce and Iconology}

Habitus, Embodiment, and the Analogy between Philosophy and Architecture

\section{Tullio Viola}

\section{AUTHOR'S NOTE}

I received very generous comments on previous drafts of this article from Horst Bredekamp, Maria Luisa Catoni, Sascha Freyberg, Carlo Ginzburg, Lydia Goehr, Helmut Pape, Salvatore Settis. I thank them all. Laure Astourian and Julian Smith-Newman have much improved my English. Without the many conversations with the late John M. Krois this research would have never been born.

\section{Introduction: From Peirce to Sociology, via Panofsky}

1 The starting point of this paper is a thus far barely remarked upon - and at first blush somewhat negligible - textual consonance: both the philosopher Charles S. Peirce and the art historian Erwin Panofsky have written about the classic analogy between Gothic architecture and Scholastic philosophy.

2 Panofsky, of course, dedicated one of his most famous and debated books - the 1951 Gothic Architecture and Scholasticism - to the topic; while Peirce addressed it almost in passing, first in his renowned review of Berkeley, and then, even less systematically, in a number of subsequent manuscripts and papers. This asymmetry notwithstanding, and also in spite of the fact that no direct connection among these texts is extant, I shall maintain in what follows that such a convergence does have a theoretical weight: one that may help us better to assess and historically locate the more general contact points between Peirce's thinking and iconology.

3 Panofsky did in fact know of Peirce, whom he quoted in a number of passages dealing with the justification of iconological method. All these passages refer to one single phrase 
of the American thinker, one which at first seems peripheral but which actually (as we shall see) goes to the heart of his philosophy: "it is the belief men betray, and not that which they parade which has to be studied." 1 This brief sentence, which Panofksy took from his student Edgar Wind, will help reveal the broader story of an early, thus far neglected, yet at the same time momentous line of reception of Peirce's philosophy.

Although my focus in the rest of this article will be on the art-historical tradition, however, it is important to add here that this line of reception did not stop with Panofsky. Albeit not altogether explicitly, it also played a crucial role in the genesis of Pierre Bourdieu's sociology.

5 To clarify this, let me say in advance that I shall locate much of the common terrain between Peirce and Panofsky in the notions of habit and habitus: two distinguishable yet tightly interwoven concepts, which since their Greek origin have occupied a central position in Western philosophy. Originally the scholastic translation of Aristotle's hexis and echein, the Latin term habitus has traditionally designated the philosophically stronger (and ontologically more committing) notion of the two: the system of abiding dispositions which define human nature in a broad sense. At the beginning of the twentieth century, founding thinkers of the social sciences such as Durkheim, Weber and above all Mauss still heavily relied on this strong, by and large Aristotelian idea of habit; but the naturalization of the concept put forth by behaviorism increasingly caused sociologists and anthropologists to do away with the term. ${ }^{2}$ As of the late 1960 s, it was Bourdieu who most strongly opposed this tendency, famously making of habitus the lynchpin of his methodology. Yet scholars do not always realize how important Panofsky was for Bourdieu's rediscovery of the scholastic term.

6 Devoting much of his early work to the sociology of art and education (as well as to the cultural meaning of architecture), ${ }^{3}$ Bourdieu came to recognize in Panofsky an important ally in his methodological approach. In 1967 he translated Gothic Architecture and Scholasticism, and accompanied the text with a postface that reflects on habitus as the decisive tool for circumventing the shortcomings of both structuralism and positivism. Not only habitus, but also Panofsky's more general problem of iconological meaning appeared to Bourdieu to point towards that unwitting dimension of agency which, mainly formed through education, connects individuals to the broader social context in which they are embedded. ${ }^{4}$ At the same time, Edgar Wind's 1936 article on "Some Points of Contact between History and Natural Science," which is precisely the text that contains Peirce's quotation, helped him to better underline the methodological assumptions of Panofsky's model; he thus included a long excerpt from it in the 1968 handbook on sociological method. ${ }^{5}$ And although this fact seems to have gone totally unnoticed, in both the 1966 paper on "Intellectual Field and Creative Project" (in which the notion of habitus already appears) and the introduction to the book on photography Bourdieu literally quoted Peirce:

To relate the works produced by an age to the educational practices of the time is [...] to provide oneself with one means of explaining not only what they say but also what they betray in so far as they participate in the symbolic aspects of an age or society. ${ }^{6}$

Only a few years later, Bourdieu would partially change his mind about Panofsky, beginning to see the latter's methodological stance as merely restating the same intellectualist fallacies that flawed structuralism. ${ }^{7}$ As he explicitly wrote, it was another art-historical masterpiece - Baxandall's Art and Experience (1972) - that had prompted his 
change of opinion; ${ }^{8}$ but I am also tempted to recognize in it the traces of a dialogue with Émile Benveniste. In an essay from 1969 which also dismissively touches upon Peirce, the French linguist had suggested that Panofksy's book on Gothic architecture be construed as relying on a semiotic basis, thus backing a Saussurian reading of iconology (also advocated, in the same years, by Giulio C. Argan) which inevitably downplays the role of habit, and reduces the significance of a comparison with Peirce to a vaguely similar semiotic interest. ${ }^{9}$ Yet if, by contrast, the notion of habit is given proper weight - as I shall attempt to do in what follows - this similar interest will not only appear less casual; but the thread that holds together Peirce's pragmatism, Panofsky's iconology and Bourdieuian sociology will also gain significance. All the more so as Peirce's treatment of habit is also the origin of that pragmatist theory of action which subsequently proved capable of influencing American social thought; and Panofsky's iconological take on the same concept reveals debts and overlaps with the classics of sociology which go far beyond Bourdieu. (As we shall see, the dialogue with Karl Mannheim is particularly important in this respect. $)^{10}$ For all these reasons, the following pages, while dwelling on the apparently remote subject of Gothic churches, should also be read as a chapter in the history of the exchanges between Pragmatism and Social Theory. ${ }^{11}$

8 I shall begin with a few prefatory observations on the parallel between architecture and philosophy. Although cursory, they intend to suggest that, once historically contextualized, the seemingly casual textual correspondence between Peirce and Panofsky can reveal significant aspects of their works. At the same time, these observations will serve as a touchstone for bringing to light similarities, shared premises and common sources between the two thinkers. I shall then proceed by presenting Peirce's and Panofsky's arguments. My strategy is to locate these arguments within the broader web of the two authors' lifelong concerns, thus letting the similar purport of their contentions come to the fore. In doing so, I also aim to give proper weight to some of Peirce's observations on art, which, however sparse and clumsy they may be, deserve a more serious consideration than they have been accorded so far. Finally, I shall dwell at length upon the philosophy of Edgar Wind, as the crucial link between the two authors; and attempt to draw some theoretical conclusions.

\section{Philosophy and Architecture: the Significance of a Parallel}

The history of the attempts to relate Gothic architecture and Scholasticism is by no means confined to Peirce and Panofsky. Both belong to a longer and philosophically consequential line of thought. Meyer Schapiro locates its birthplace in the last page of Kant's Beobachtungen über das Gefühl des Schönen und Erhabenen, which criticizes the taste of the Middle-Ages as emanating from "grimaces" (Fratzen). Not limited to architecture, Kant writes, this taste was also reflected in costumes as well as in the "tausend Schulfratzen" concocted by men of science. ${ }^{12}$

During the nineteenth century Kant's idea was taken up over and over again. Michelet, Semper and Wölfflin are only a few of the scholars who dealt with it, typically less for the sake of the specific historical problem than as a way of broaching the general issue (Hegelian in some measure) of the relation between the art and the culture of a period. ${ }^{13}$ An indicator of the emblematic status the topic came to acquire, the assertion of such an 
analogy proved much stabler than the rationales alternatively proposed to account for it; the very problem of finding a way to connect the two phenomena became the pars pro toto for a much more abstract question.

11 Why did this happen? The almost perfect chronological overlapping of the two terms of the analogy is hardly a sufficient explanation. Paul Frankl has suggested that the very history of the word "Gothic," which from a strictly architectural meaning came to denote a broader range of cultural phenomena, has gradually led to the problem Panofksy addressed..$^{14}$ Still more important, however, is the phenomenon of nineteenth-century "historicist" architecture, both in its revivalist and eclecticist version, which caused architects to pose the question of their social and historical embeddedness more emphatically than other artists or scholars. Within this framework, the protagonists of the Gothic Revival (a movement that stretched well beyond architecture) in turn typically colored their rediscovery of the Middle Ages with traditionalist, Romantic if not conservative assumptions, championing the weight of tradition and collective historical forces as opposed to meta-historical laws. Now, as we shall see (though the matter deserves to be explored much more deeply) these assumptions permeate Peirce's keen interest in the in the Middle Ages as well; so that when cast into this context, his reflections on the Gothic may offer an unexpected occasion to shed new light on his broader philosophical temperament.

12 A few considerations are also in order with regard to philosophy's age-old attraction to architecture. Once again it is Kant who first comes to mind, and his notion of architectonics, which Peirce heavily relied upon in his own reflections on the nature of philosophy. Albeit not so masterfully as Wittgenstein, Peirce even practiced architecture. Since the very years in which he worked on his Architecture of Theories, he directed the renovations of his own country house, "Arisbe," which he had also planned to turn into a center of philosophical inquiry - the incarnation, as it were, of that "philosophical edifice" that he was at pains to erect in his writings. ${ }^{15}$ And yet this thread, too, ends up leading us to Scholasticism: much prior to Kant and Peirce the parallel between architecture and philosophy had been proposed by Thomas Aquinas. At about the same time in which, in France, the figure of the (Gothic) architect began to be invested with a new dignity, Thomas was able to recover the Aristotelian sense of the term and to label philosophical activities "architectonicae" for their capacity to confer order on things and govern secondary sciences. ${ }^{16}$

\section{Peirce's Review of Berkeley}

In the October 1871 issue of the North American Review, Peirce published a lengthy essay on Alexander Fraser's new edition of George Berkeley's works. Despite its apparently occasional nature, this is a seminal and in some ways unsurpassed text within Peirce's oeuvre, both for its conceptual depth and for the breadth of knowledge and interests it masters and brings into play. Peirce took the review as the occasion for a much wider reflection on the fundamental question that preoccupied him at that time: the quarrel between nominalism and realism. Focusing exclusively on the British tradition, he traced the history of this dispute from its scholastic origins (which he had thoroughly studied during the late 1860s) up to nineteenth-century positivism, with a remarkably keen eye for the evolution of ideas in time and their documentable transfers from one author to another. 

the philosophical gist of the controversy. ${ }^{17}$ In his version, the disagreement between the two doctrines really amounts to a different conception of reality. Nominalism conceives it as what is external to the mind and is not created by it: the "fountain of the current of human thought," independent from and directly influencing it precisely because of its being outside of the mind. The realist, on the contrary, sees the real as "the unmoving form" which will be reached in an indefinitely distant future by means of converging trajectories gradually doing away with the partialities of individual viewpoints. Far from being external to the mind, reality is hence independent "not [...] of thought in general, but of all that is arbitrary and individual in thought," and presupposes the idea of a community of inquirers gradually approaching consensual truth: "there is a general drift in the history of human thought which will lead it to one general agreement, one catholic consent." 18

As is easy to perceive in this last sentence, Peirce read the logical "technicalities" of the controversy as ultimately bearing on a much more general (or ideological) bundle of issues: something every man, "if he is not less than man," will have to confront. As he saw them, the morally "debasing," materialist and individualist drives that dominate modern science are of a piece with the nominalist outlook. Realism, on the contrary, is only upheld by "the most conservative minds" ${ }^{19}$ among which he clearly counted himself.

In order to render more plausible the realist view of reality as not separated from the mind, Peirce resorted to Duns Scotus' distinction between "two ways in which a thing may be in the mind, - habitualiter and actualiteri" (which is in turn dependent on Aristotle's discussion of first and second actuality with regards to sensation). ${ }^{20}$ While the universal does not need to be conceived actualiter in order to be real, it does have to be in the mind habitualiter; that is, such that it "can directly produce a conception [...] by virtue of mental association" and "independent[ly] of consciousness." ${ }^{21}$ These words reveal better than many others the extraordinary fecundity of Peirce's notion of habit, and its ability to serve as the virtual meeting point of the different threads of his philosophy. Its more properly metaphysical purport, here only adumbrated, will be apparent in the later theory of categories, in which the process of habit-forming is tantamount to the category of concepts and signs (thirdness), as opposed to the realms of sheer actuality or "brute action" (secondness) and pure possibility (firstness). But the notion also plays an especially crucial role in the formulation of Peirce's pragmatism (according to which a belief is only definable in terms of habits of action), as well as in his reflections on the mind, perception and the self. From our perspective, it is particularly noteworthy that Peirce came back to Scotus' habitualiter-actualiter distinction precisely in the 1905 article that also contains the distinction between "parading" and "betraying," using it in his attempt to better articulate his view of the unconscious as not qualitatively opposed to consciousness but rather continuously shading into it. ${ }^{22}$

The role that Berkeley plays in this scenario is a complex one. His conception of reality, Peirce argues, is akin to the realist one only at the surface: at bottom, the rift he established between mind and matter in fact makes him a nominalist and a Platonist at once. ${ }^{23}$ At the same time, his theory of perception and knowledge is of outstanding importance for modern thought. This is a trait Peirce would return to more emphatically thirty years later, in another review of the second edition of Fraser's work. There we read that "Berkeley is, in truth, far more entitled to be considered the father of all modern 
philosophy than is Kant"; and "it was he, more than any other single philosopher" who should be regarded as the father of pragmatism. ${ }^{24}$

The precise reason for such a bold statement can be found in a manuscript of 1911: "I think the idea [of pragmatism] was suggested to me by Berkeley's two little books about vision." ${ }^{25}$ Peirce was referring to the New Theory of Vision (1709), followed by the Theory of Vision Vindicated. In these works Berkeley put forward his ideas about the inferential nature of vision and its dependency on touch or proprioception which have represented the paramount source, from Helmholtz to Gombrich, of all subsequent reflections on perception as unconscious inference. ${ }^{26}$ Although the matter is much more complex and controversial with regards to his later period, ${ }^{27}$ Peirce's early theory of perception may be easily inscribed into this tradition. His writings from the late 1860s make clear that he saw in Berkeley's work not only a milestone in the history of associative psychology, but a fundamental benchmark for his reflections on the inferential and habitual character of perception and the non-existence of intuitive cognitions which eventually led to the celebrated "anti-Cartesian" essays of 1868-69.28

\section{Peirce the Historian}

It is within this framework that the comparison between Gothic architecture and scholasticism, presented in the very first pages of the review, gains its most immediate significance. Peirce wished to introduce the issue of nominalism not only as a theoretical problem, but also as a chapter of what he called "[m]etaphysical history," or the history of philosophy as "the best representative of the mental development of each age," and which he invited historians to address together with the history of other aspects of human affairs such as society, government, war, law. It is by dint of these comparisons that we can "trace the significance of events for the human mind," and discern deeper regularities or transversal analogies. ${ }^{29}$

The phenomenon that most interested Peirce in this respect was the "revolution of thought" that occurred in twelfth-century Europe, the causes of which he looked for in the Crusades and the effects of which he found in fields as diverse as commerce, law, ecclesial history, and finally philosophy and art. "Indeed" - he claimed - "if any one wishes to know what a scholastic commentary is like, and what the tone of thought in it is, he has only to contemplate a Gothic cathedral." ${ }^{30}$

21 Albeit cursorily, Peirce put forth four different rationales for this analogy. The first shared feature between the two phenomena is a "heroic" religious faith and a "complete absence of self-conceit on the part of the artist or philosopher." Both kinds of works were catholic, that is, they were not meant to "embody" the author's ideas as "the universal truth." This also entails a scrupulousness that would be unthinkable in other contexts: the Schoolmen's ruminations on the most abstract theological questions no longer appear gratuitous if one takes seriously their unswerving trust in biblical revelation. The second shared trait is "a detestation of antithesis or the studied balancing of one thing against another [...] - a hatred of posing which is as much a moral trait as the others." The third is the "increasing sense of immensity" emanating from both. Finally, Gothic architecture and scholasticism are similar in the way they eventually faded, losing touch around the same time with their religious impulse, and sinking "first into extreme formalism and fancifulness, and then into the merited contempt of all men." ${ }^{31}$ 

Gothic architecture did he rely on? An attempt to answer these questions seriously must begin from the fact that at the moment he was writing his review of Berkeley, Peirce had just come back from the first of the five European journeys he made during his life. ${ }^{32}$ Sailing from New England on June 1870, he spent almost nine months in Europe, on a tour that brought him to a large number of northern and Mediterranean countries. The main goal of the journey was to make preparations for the observation of a solar eclipse; but Peirce also took advantage of his travels to cultivate scientific relationships, as well as to visit libraries, purchase books and photographs, and get acquainted with European art. The papers conserved at Harvard contain some private letters and diaries which, ignored by scholarly editions, offer a glimpse into Peirce's interest in the art and architecture of the countries he visited. ${ }^{33}$

In particular, the image of Peirce that emerges from these documents is - to borrow the words he himself would use five years later, during his second trip to Europe - that of an "enthusiastic admirer of the Gothic." ${ }^{34}$ Both the letters and the private notes contain numerous records of his visit to Gothic churches in England, Italy, Spain, Switzerland and France (with the important exception of Île-de-France, where he did not go because of the war), which reveal, in addition to admiration, a familiarity with technical vocabulary as well as a distinct curiosity for the art-historical debate. ${ }^{35}$ Thus on January 30th, in Canterbury, Peirce purchased Robert Willis' Architectural History of Canterbury Cathedral (1845). ${ }^{36}$ Still more significant, though, is the note he had jotted down ten days before, while in Strasbourg: "Saw only cathedral. [...] In evening Z[ina] [his wife] read Whewell's Notes on German Churches. Very pleasant." ${ }^{37}$

The reference, of course, is to the eminent British philosopher and scholar William Whewell, the third edition of whose Architectural Notes on German Churches came out in $1842 .{ }^{38}$ Whewell is known to have been a decisive intellectual model for Peirce; and indeed the affinities between the two are significant. To begin with, both were great polymaths. But it was primarily the quarrel with John Stuart Mill on the logic of inductive sciences that sparked Peirce's deepest admiration. Against the nominalism of the latter, Peirce saw in Whewell the incarnation of the realist scientist, capable of reconciling the demands of scientific inquiry with philosophical soundness. A clear statement to this effect can be found precisely in that final page of the Berkeley review in which Peirce attacked the rampant nominalism of modern times: "science as it exists is certainly much less nominalistic than the nominalists think it should be. Whewell represents it quite as well as Mill." ${ }^{39}$

As becomes evident in his renowned History of the Inductive Sciences, a seminal hallmark of Whewell's philosophy of science is its inherently historical character. This trait deeply attracted Peirce, as is testified by the words he devotes to it as early as the 1865 and 1869 lectures series on the philosophy of science and British logicians. Indeed, it can be affirmed that both Peirce's lifelong interest in history and his overall methodology decisively depend on his encounter with the man whom he dubbed 'the most profound" among modern philosophers of science. ${ }^{40}$

26 Appealing to the famous Kantian adage on the relation of concepts and intuitions, Whewell put at the center of his reflections the thesis that "all facts involve ideas unconsciously; and thus the distinction of facts and theories is not tenable." ${ }^{41}$ This entails a denial of pure observation, or of any "colligation of facts" that is not determined by previous ideas. Paraphrased by Peirce: "observation as distinct from mere gazing consists

European Journal of Pragmatism and American Philosophy, IV - 1 | 2012 
in perception in the light of a question." ${ }^{42}$ Whewell's engagement with a "philosophical" history of science is also derived from this focal point. As Peirce puts it, historical colligation of facts has the pretension, in Whewell's writings, not to content itself with extrinsically giving "a color of verisimilitude" to a theory already deduced; rather, it aims at representing the very gate through which philosophical ideas should be inductively formed and examined. ${ }^{43}$

The notion of history of science which emerges from the History of Inductive Sciences is a very broad one. Digressions on the history of philosophy, art and society are plentiful. It is not difficult to relate this quest for parallels between cultural phenomena to Whewell's broader philosophical stance. If the uncontaminated eye is a myth, art is more liable to embody ideas of the same kind as those examined by philosophers or scientists. If ideas are not brought about a priori, but through a continuous interaction with the external world, then the latter will be more easily regarded as intellectually pregnant. This is important for us, since Whewell's chapters on the Middle Ages are full of hints at correlations between architecture on the one hand and science, philosophy, or more general intellectual traits of the epoch, on the other. ${ }^{44}$ Whewell does not propose a straightforward analogy between Gothic architecture and scholastic philosophy; but he gives enough hints in that direction that we can imagine Peirce having these pages in mind, too, when giving shape to his ideas.

A number of writings of the 1890s confirm the influence of Whewell in both Peirce's conception of historical knowledge and the important role therein played by Gothic architecture. In the renowned Evolutionary Love of 1892 (which closes the series opened by The Architecture of Theories), Peirce definitively systematized his evolutionary conception of rationality. And once again Gothic architecture appears: this time as a the starting point for a reflection on the problem of the "spirit of the age," and the related fact that ideas occur "simultaneously and independently to a number of individuals of no extraordinary general powers." ${ }^{45}$ Then the Lowell Lectures series on the history of science Peirce held the same year (and which I regard as a sort of empirical counterpart to the work on evolutionary love) opens with an apology of "the method of Whewell" in historical research, of whom Peirce presented himself as a disciple. ${ }^{46}$ In these texts a number of scattered reflections can also be found on the mutual relations among artistic, scientific and philosophical manifestations of the same epoch, which clearly depend on Whewell.

In a slightly later text on the history of ideas, Peirce returned to the revolution of thought of 1200 , and once again related (albeit more subtly than in 1871) its two major outcomes: scholastic philosophy and Gothic architecture. Regarding the latter, he tackled the vexed topic of its origins, dismissing as "ridiculous" the hypothesis that it has come from the Arabs. "No" - he wrote, - "Whewell was right. [Gothic] was simply forced upon the architects by their desire to open large spaces, and [...] to use compartments that were oblong not square." He then went on to describe the architects' "train of thought" with words that recall logical reasoning:

The men of that time were not content to go on building as they had always done; they wanted to do better. In order to do better they must have wider aisles. In order to accomplish this they must have oblong compartments. Here they had to think hard to solve a new problem [...]. The result was the Gothic arch. But they did not stop with simply making a gothic arch. They carried it to its logical conclusion, a lofty roof. A lofty roof implied slender columns. [...] What a wonderful train of thought this was! How strong and simple in every step! The effect of a Gothic 
church is to embody that intense yearning for something higher [...] which marks

the fall of pride. ${ }^{47}$

30

\section{Panofsky's Argument} Berkeley is not an accidental or insignificant digression. Among other things, it epitomizes some basic aspects of Peirce's philosophical approach to history. No wonder that, years later, he considered the topic worth addressing again. ${ }^{48}$ Partially stirred by his interest and his high respect for medieval philosophy, Peirce resorted to this challenging, much-debated and far-reaching issue to come to grips with an aspect of his methodology that we can also discern in his notes on historical periods other than the Middle Ages. the other thinker I would like to consider here: Erwin Panofsky. Indeed, Panofsky's Gothic Architecture and Scholasticism should be seen as a late reflection on the central preoccupation of his intellectual life: the link between ideas and figurative artifacts, and more specifically, the question of the latter's "intrinsic meaning," or relation with the "underlying principles which reveal the basic attitude of a nation, a period, a class, a religious or philosophical persuasion." ${ }^{49}$ At the same time, Panofksy touched upon some broader philosophical issues (the nature of perception and agency, the need to reconcile the conflicting demands of reason) which reveal his sympathy for the scholastic thinking with which he was dealing.

The book opens with a defense of the quest for analogies among different cultural phenomena of a single epoch. Risky as this enterprise necessarily is, it is nonetheless inescapable for the historian who wishes to give an intelligible shape to the flux of time. The case of Gothic architecture and Scholasticism, however, is particularly favored, in that it rests upon a striking congruence in the "purely factual domain of time and place." Early Scholasticism and Early Gothic were born around the same years (the middle of the twelfth century) and in the same place: the area surrounding Paris. They matured and reached their "classical" period at about the same time. Finally they entered their decline together, in the age of Ockham, Eckhart and Giotto. ${ }^{50}$

But the main thesis of the book is that "in the period from about 1130-40 to about 1270" the link between philosophy and architecture goes well beyond this geographical and chronological coincidence. What is more, this link is "more general than those individual (and very important) 'influences'which are inevitably exerted on painters, sculptors, or architects by erudite advisers." It is, in short, a causal relation, but one which "comes about by diffusion rather than by direct impact." The fulcrum of such a relation is what Panofsky called the mental habit that Scholasticism allegedly instilled into architects. ${ }^{51}$

Revealing an interesting weaving between the method of inquiry and its object, Panofsky traced back this notion to Thomas' discussion of habitus as a "principle that regulates the act" ("importans ordinem ad actum")..$^{52}$ More precisely, what philosophers and architects actually shared was a common modus operandi, which was dictated in turn by "the very raison d'être of Early and High Scholasticism": the need to reconcile the demands of reason and faith, thereby salvaging the unity of truth. Two main operative or methodological principles develop from this fundamental trait. The first is manifestatio. Reason's task of elucidating the articles of faith was generalized into an all-embracing rhetorical stance

European Journal of Pragmatism and American Philosophy, IV - 1 | 2012 
that aimed at "clarification for clarification's sake" and at making intellectual contents as perspicuous as possible at the level of their mode of expression. The second principle is concordantia, or the quest for the "acceptance and ultimate reconciliation of contradictory possibilities" which sprang from the tension between the wholehearted faith in the auctoritates and a sense of the contradictions into which they sometimes fell.

Both these rhetorical or methodological features had their correspondence in the domain of Gothic churches. As for concordantia, Panofsky tried to show that the different "solutions" to the "problems" gradually tackled by Gothic architects have the same dialectical and conciliatory progress of the Scholastic quaestiones: videtur quod - sed contra - respondeo dicendum.

But it is manifestatio that is especially interesting. Panofsky quoted a renowned assertion from Thomas Aquinas, and gave an interpretation of it as essentially in agreement with those Gestalt psychologists who described perception as always "intelligent" or interpretive..$^{53}$ Thomas wrote: "The senses delight in things duly proportioned as in something akin to them; for the sense, too, is a kind of reason as is every cognitive power" ("nam et sensus ratio quaedam est, et omnis virtus cognoscitiva"). ${ }^{54}$ In accordance with this tenet, Panofsky argued, the domain of visuality was treated as intellectually charged in the Scholastic period, and figurative artifacts (architecture above all) as bearers of a visual logic that made manifest in the realm of materiality the abstract principles embodied in it. This means, among other things, that the notions of functionalism or illusionism cannot be applied to Gothic architecture in any meaningful way.

\section{Habit and Iconological Method}

The polemic against the notion of a "pure eye" is one of Panofsky's oldest motifs. It can already be found in his first theoretical paper, the 1915 criticism of Wölfflin, which attacked precisely the latter's idea of a clear-cut divide between a psychologically or epistemically neutral (individual) and a content-laden (super-individual) root of style between Auge and Gesinnung. Panofsky denied the existence of a purely optical component of perception, as well as the related dichotomy between form and content. The succession of artistic styles depended on changes not only in the Anschauung der Welt, but in the Weltanschauung..$^{55}$

The implicit Kantian standpoint of this essay emerged with clarity in Panofsky's subsequent publications. In the renowned paper on the Kunstwollen, Panofsky took pains to construe Alois Riegl's notion in a non-psychological way - as the immanenter Sinn of works of art - with an explicit eye to Kant's transcendental philosophy. ${ }^{56}$ But it is the writings around 1924 (the year during which he definitively confronted the work of Ernst Cassirer) ${ }^{57}$ that mark a number of especially interesting developments. In a work directly related to the Kunstwollen paper - Über das Verhältnis der Kunstgeschichte zur Kunsttheorie we find the first hint of a dialogue with his most gifted pupil, Edgar Wind, who in his doctoral dissertation had put forward a view of works of art as always characterized by the eternal polarity of Fülle and Form. In a similar vein, Panofksy attributed to the intrinsically polar character of works of art the methodological necessity of conceiving the latter as temporary solutions to problems that manifest themselves in antithetical 
form. (This view runs through Panofsky's whole oeuvre, up to his book on Gothic architecture).$^{58}$

The same essay is also important for us because of its reference to Karl Mannheim's sociology of knowledge. In the famous 1923 article on the interpretation of Weltanschauungen, Mannheim had resorted to Panofsky's work on Riegl in order to support his notion of Dokumentsinn: the unintentional stratum of meaning which hints at the worldview a particular cultural object presupposes - or, in case of human behavior, its general "Habitus." ${ }^{99}$ In his subsequent work, Panofsky reciprocated the acknowledgment when he claimed that it is precisely the conception of cultural objects as solutions to antithetical problems that may legitimate the quest for parallelisms. ${ }^{60}$ The discussion with Mannheim then continued in a contemporary review of a book on Giotto, which presented the occasion for a discussion of Weltanschauungen in the context of Medieval studies. Here we also find a first allusion to Thomas' "et sensus ratio quaedam est," construed in an anti-subjectivist and Aristotelian sense. ${ }^{61}$ (A true guiding thread of his ruminations, Panofsky discussed Thomas' sentence yet again in a review from 1934). ${ }^{62}$

Panofsky's technical use of the notion of habit has been usually regarded as a novelty of his 1951 book. However, there are some precedents. In the writings of the German period, some occurrences of the term "Habitus" (in the Latin form) can be found, with the circumscribed sense of "posture" or "physical attitude." ${ }^{63}$ But a letter from 1938 registers an important turning point. Asked to sum up his general lines of research, Panofsky wrote:

On the one hand I have tried to do what I shall call "Iconography," if it was not for the somewhat terrifying implications of this term, that is: to interpret the subject matter and content of works of art on the basis of contemporary sources, and to connect with [sic] the general habitus of the period. ${ }^{64}$

The term "Habitus" is placed here at the very center of Panofsky's enterprise, and is noticeably expanded in its semantic scope - probably also with an eye to the intellectual evolution of Mannheim during the thirties. Later, in a letter from 1946, Panofsky wrote of the "mental habit of duplicity" pervading Mannerist architecture ${ }^{65}$ During the years that separate these two texts he gradually embarked on his more than ten-year research on Gothic architecture, which, as the private correspondence shows, was dotted with hesitations and loaded with large theoretical expectations. ${ }^{66} \mathrm{Up}$ to that point, the dialogue with Mannheim had focused on the "documentary" (and abductive, we may add) character of iconology, as is well attested by the classical statement of Panofskyian method, the 1932 Zum Beschreibung und Inhaltsdeutung von Werken der bildenden Kunst. ${ }^{67}$

The first version of this celebrated paper - rewritten and translated into English in 1939, then slightly reworked in 1955 - explicitly refers to the Hungarian sociologist. It also pushes further the dialogue with Edgar Wind, regarding the latter's observations on the inherently circular nature of both scientific and historical inquiry. But most importantly, it is here that Peirce's philosophy makes its first appearance. In the midst of his discussion of the unwitting character of documentary meaning (Martin Heidegger's notion of the Ungesagte appears, too), Panofsky quotes "einen geistvollen Amerikaner" and his distinction between what a man "parades" and "what he betrays." The 1939 version of the paper suppresses this reference to Peirce, together with the names of Heidegger and Mannheim, stressing instead the proximity with Cassirer's philosophy of symbolic forms. But no less than three subsequent allusions to Peirce's phrase can be 
found elsewhere in Panofsky's writings, the most consequential among which is in the introductory chapter of Meaning in the Visual Arts, written in 1940:

Content, as opposed to subject matter, may be described in the words of Peirce as that which a work betrays but does not parade. It is the basic attitude of a nation, a period, a class, a religious or philosophical persuasion - all this unconsciously qualified by one personality, and condensed into one work. ${ }^{68}$

Scholars have often diagnosed a neat discontinuity in Panofsky's oeuvre. After his American exile, he abandoned his mother tongue, dramatically changed his rhetorical style, and - so it is usually maintained - grew dissatisfied with the heavy philosophical tone that permeates his early work. I do not wish to deny the truths in this picture; yet the threads I have been following suggest a more nuanced story. Far from being the product of a philosophically disengaged mind, the book on Gothic architecture recapitulates a number of theoretical preoccupations that go back to the 1910s and presuppose the dialogue with the whole gamut of thinkers Panofsky confronted during his life. Granted, he by and large abandoned the Kantian standpoint of his early phase, to the advantage of a more pluralistic and empirical stance. Perhaps the later emphasis on habit might allow us to speak of a more Aristotelian, or even pragmatist solution to his lifelong concerns.

\section{A German Pragmatist: Edgar Wind}

It is certainly possible to account in part for the consonances between Peirce and Panofsky which have so far emerged by referring to a common philosophical background (Kant and the Aristotelian tradition, first of all; but also post-Kantian aesthetics) ${ }^{69}$ Nor would it be too difficult to point at mediating figures who pushed Panofsky's thought in directions similar to Peirce's. Let me again mention Karl Mannheim, and his late, extensive use of the notion of habit of thought. But Ernst Cassirer, too, though he did not read Peirce, bears affinities to the latter which are far from random. ${ }^{70}$

If, however, we are interested in grasping the details and the scope of Panofsky's actual acquaintance with Peirce, it is to Edgar Wind that we must turn.

A student of philosophy and art history, Wind arrived in Hamburg in 1920 in order to work under Panofsky. ${ }^{71}$ He obtained his doctorate with a thesis on Äesthetischer und Kunstwissenschaftlicher Gegenstand which, as already mentioned, strongly impressed his mentor..$^{72}$ Driven by the economic crisis, he left Germany in 1924 for the United States, where he stayed until 1927, first in New York, then as a philosophy instructor at the University of North Carolina. He thus made the acquaintance of the American philosophical world, the influence of which on his thought was profound, as is clearly attested by his Experiment und Metaphysik, published in 1934 but presented as his Habilitationsschrift in Hamburg in 1929 and already substantially anticipated in a talk given at Harvard three years before. ${ }^{73}$ Wind was among the very first German scholars to write extensively on the philosophy of Whitehead, and seriously to confront Peirce's writings..$^{74}$ Later in his life, he would go so far as to affirm that he had had only two "masters": Aby Warburg and Peirce himself. ${ }^{75}$

The American philosopher Sidney Hook is likely to have played an important role in Wind's discovery of pragmatism. Hook was a student of Dewey's at Columbia when he met Wind; and his doctoral dissertation, Metaphysics of Pragmatism (published in 1927) bears implicit witness to a close dialogue with his German colleague. ${ }^{76}$ Largely devoted to a bold 
defense of Dewey's instrumentalism, Hook's text heavily relies on Peirce, as contrasted with the "nominalist" James. Uncommon among philosophical books of the period, it opens with a picture - William Blake's The Ancient of Days - as a way of introducing the main features of Hook's conception of the instrument (a notion whose prominence "is not an evasion of a metaphysics but a challenge to one"): ${ }^{77}$ its semiotic status, the circular relation it maintains with the world to which it belongs. From this focal point Hook also derives a number of observations on the active character of perception and the philosophy of space and time which come very close to Wind's ideas. ${ }^{78}$

Even more importantly, in 1924 Wind met the pragmatist philosopher Morris R. Cohen (whose student and colleague, Ernst Nagel, would positively review Wind's book ten years later). ${ }^{79}$ Wind found Cohen "very pleasant and clever," as we can read in a 1931 letter to Panofsky, in which the latter - then in New York - is given a number of interesting contacts..$^{80}$ In 1916, Cohen had edited the first journal issue entirely dedicated to Peirce; and only one year prior to Wind's arrival in America, he had published the first collection of Peirce's writings, containing many of his most famous papers. ${ }^{81}$ It is most likely through this path that Wind grew directly acquainted with Peirce's writings.

The Habilitationsschrift defended at the University of Hamburg in 1929 (under the supervision of Cassirer and Panofsky) is by far Wind's most important philosophical work. Its absence in today's debate is an undeserved fate that goes back to its having appeared "dead-born" 82 in the midst of dreadful political circumstances. Compared to Hook's witty but facile Pragmatism, Wind's work stands out for its erudition, its intellectual breadth and its philosophical rigor. Its main goal - a confutation of Kant's transcendental dialectics - may not be irrefutable from a Kantian standpoint; but the first part of the book sets down a theory of Verkörperung or embodiment which makes of Wind one of the major, if neglected, figures of European pragmatism..$^{83}$ These pages also exerted a strong influence on Panofsky, who constantly came back to them in his reflections on iconological method.

Wind's central contention ${ }^{84}$ is that metaphysical questions - conceived on the model of Kantian antinomies, as questions that bear on the totality of the world - are in principle always decidable, for they necessarily entail consequences in the domain of experience which will prove verifiable in the long run. The act of measuring through which the scientist, in the experimental situation, interrogates reality, never concerns solely the single fact with which it primarily deals, but always tests a whole theory, together with its metaphysical presuppositions. Facts ought not to be conceived as unrelated or immediately given data; experimental results always have a metaphysical bearing.

The ultimate reason for this fact is to be found in the very nature of the measuring instrument, which, being itself part of the same world to which it attends, cannot but presuppose or embody the same regularities of nature which it is meant to test. This sort of circularity - "methodical" or hermeneutic rather than vicious - is proper not only to the scientific instrument, but also to the historical document, which is also part of the same world with which it deals. Natural sciences and Geisteswissenschaften are thus unified under the general principle of the "internal determination" (innere Grenzsetzung), or "organic" relation of part and whole.

52 Scientific instruments and historical documents thereby reveal their "symbolic ", or semiotic nature, on which the principle of the internal determination ultimately depends. Being itself part of the world to which it refers, every "symbol" (or sign) can have a claim to validity only insofar as it entails perceivable effects of some sort. To put it in slightly 
different terms: "symbols are 'real' only to the extent in which they can be embodied in an experimentum crucis whose outcome is directly observable." 85

With this general rule Wind innovatively merged the polar theory of the symbol he derived from Warburg (the symbol is a janus-faced entity, in which sensible matter always embodies a spiritual force, and which always swings between the two poles of Verinnerlichung and Entäußerung) $)^{86}$ with the "pragmatic maxim" Peirce set forth in the 1877 essay on the How to Make Our Ideas Clear - a text Wind referred to both in the 1934 preface to his book and in another paper from the same year. ${ }^{87}$ More importantly, however, it is the very notion of embodiment that stems from Peirce. The term recurs many times in Peirce's papers. In its most technical occurrences, it indicates the relation that holds among the three fundamental metaphysical categories. The thirdness-related elements of reality can be such only as long as they are embodied, that is they govern material realities; otherwise, they deteriorate into pure abstraction. In particular, it is the nature of thought that Peirce described through the notion of embodiment: "Thought has no being except in so far as it will be embodied, and the embodiment of thought is a sign." 88 "By thought is meant something like the meaning of a word, which may be "embodied in,' that is, may govern, this or that, but is not confined to any existent." 89

The theory of Verkörperung has important repercussions for Wind's more general views on man's symbolic activities. A political action, an ethical demand or a law are merely "utopische Gedanken" if they fail to prove translatable into the realm of praxis. More importantly, artistic conceptions can become works of art only if they can be channelled into a grammar of artistic expression, and thus tested in their actual liability to be embodied or realized. ${ }^{90}$ In the same vein, Wind's theory of the symbol underpins what should be regarded as the ultimate theoretical justification of his iconological method: I mean the polemic, which we have already come across in both Peirce and Panofsky, against a clear separation between "pure vision" on one side and "pure thinking" on the other. The issue runs through Wind's whole oeuvre, from his doctoral thesis up to Art and Anarchy. In the 1931 essay on Warburg, it is employed to criticize the tendency (in Wölfflin, Riegl) to draw parallels among artistic genres without granting the right centrality to the "hantierender Mensch." ${ }^{91}$ But the overall intellectual urgency that lies behind the issue is that of fighting against what Wind, paraphrasing Plato, called "the fear of knowledge." ${ }^{\prime 92}$ Far from being irrelevant to our appreciation of works of art, scholarship and historical learning are able to enhance it. The theory of Verkörperung leaves no room for sharp boundaries between intuition and concept, image and word, seeing and thinking. Similar, in this respect, to the instrument of the scientist, the figurative artwork always embodies an intellectual dimension from which it cannot be detached.

On the other side of the same coin is Wind's polemic against the diverse spectrum of thinkers who tend to conceive of philosophy as the activity of unbounded or disembodied intellects, detached from vérités de fait and from the historicity of the concepts with which they work, or those who uphold intuitionist accounts of cognition which set men apart from the finite and conditioned nature of their epistemic practices. It is in such a context that we find the citation to which Panofksy's encounter with Peirce should be traced back. Let me quote from the 1936 paper on Some Points of Contacts Between History and Natural Science:

Whatever objections may be made to the current psychology of the unconscious, it is undeniable that men do not know themselves by immediate intuition and that 
they live and express themselves on several levels. Hence, the interpretation of historical documents requires a far more complex psychology than Dilthey's doctrine of immediate experience with its direct appeal to a state of feeling. Peirce wrote in a draft of a psychology of the development of ideas: "it is the belief men betray, and not that which they parade, which has to be studied." 93 virtually all the elements I have been gathering in these pages unfold. In order precisely to locate it in time, it is essential to bear in mind that as early as 1930 Wind probably read the original German version of the text as Probevorlesung for his Habilitation (which Panofsky no doubt attended). ${ }^{94} \mathrm{~A}$ glance at the differences between the two versions yields some unexpected results. The original version pushes the criticism of Dilthey farther than the subsequent translation by tightly linking the quote from Peirce to an exposition of Warburg's ideas. Still more significantly, some subsequently abandoned hints make clear that Wind did not have only Freud in mind when he spoke about the "psychology of the unconscious." ${ }^{\text {" O5 }}$ On the contrary, he was interested in revitalizing a number of reflections on the unconscious which are much older than Freud, and which at times diverge from his views. Although Wind did not linger over this point, thanks to contributions as diverse as his retrieval of Duns Scotus and his experiments on the Unterschiedsschwelle, ${ }^{96}$ Peirce holds an outstanding place among these studies. An appraisal of his influence on Wind or Panofksy may thus also have the beneficial sideeffect of rendering more nuanced the parallels between psychoanalysis and iconology that have been looming large over the last years.

A few more references to Peirce in Wind's oeuvre are worth recalling. A passage dating from just a couple of years after Panofsky's publication of Gothic Architecture bears new witness to Wind's attention to Peirce's notion of habit - interestingly translated here into the Latin habitus. ${ }^{97}$ Still more important, however, is a subsequent text, which Wind wrote with an eye to briefly sketching the methodological hallmarks of iconology, and which ends with a renowned Peircean sentence (though today's readers are more likely to associate it with Wittgenstein):

To convey this experience [i.e., mutually to shed light on images and text], a method of demonstration is required which is radically different from mathematical proofs. In the place of a linear logic, in which each proposition has its well-defined antecedents by which it is linked to a well-defined set of premises, we must aim for a configurational logic by which contingent arguments are interlocked. In the words of Charles Peirce, it is essential to this form of study that our reasoning "should not form a chain which is no stronger than its weakest link, but a cable whose fibres may be ever so slender, provided they are sufficiently numerous and intimately connected." ${ }^{98}$

\section{Habit, Tacit Knowledge, Iconology}

Peirce's statement concerning the difference between betraying and parading originally appeared in a footnote of his "Issues of Pragmaticism," published in The Monist in 1905. (Unlike the other texts Edgar Wind referred to, this is not comprised in Cohen's anthology.) Peirce reflected here on what he calls "critical common-sensism" as one of the footholds of his philosophy. Whilst every man's intellectual life relies on a number of unquestioned premises, these are by no means intrinsically undoubtable. The boundaries between what is doubted and what is taken for granted change from generation to generation. A historical study of these shifts is possible, and Peirce himself claimed to 
have once embarked on the enterprise, which "needs the qualities of age and does not call upon the powers of youth. A great range of reading is necessary; for it is the belief men betray , and not that which they parade which has to be studied." 99

The key-term here is, of course, belief. As I have already recalled, the pragmatic maxim can be rephrased by saying that the purport of a belief is tantamount to the sum total of possible actions which it would elicit under every conceivable circumstance. This principle dovetails with Peirce's semiotics, which asserts that a sign can be such only if it is part of a chain of other signs that interpret or reproduce it. There is a "general rule" which, though it cannot be exhausted by any of these individual "interpretants," governs (is "embodied in") the process of their production.

In the case of human agency and thought, a role analogous to this general rule is played precisely by the belief-habit. If one puts together these two prongs of Peirce's pragmatism, it follows that all actions, or products thereof, which fulfill some sort of semiotic function (from signs of greeting to figurative artifacts) do not merely stand for their primary or intended meaning, whatever it be. They are at the same time the interpretants of beliefs that, like the eye's blind spot, may be opaque to the subject's autoanalysis. Human actions and products embody or betray the meaning of such beliefs. It is thus significant that one of those "proto-iconological" observations that can be found in the Lowell Lectures of 1892 reads: "[The Greeks'] ruling intellectual passion was a passion for unity. [...] Their architecture, their decoration, their sculpture, the construction of their dramas, and of their prose writings equally betray this passion for unity." ${ }^{100}$

The accent on the unwitting dimension of habit-governed behavior calls attention to a point of contact with thinkers such as Wittgenstein, Bourdieu or Michael Polanyi. "We know more than we can tell"; the "rules" that govern human conduct can never be made wholly explicit. They constitute a different way of knowing - a practical one; or what we "attend from" as opposed to what we "attend to," in the Polanyi's terminology. ${ }^{101}$ The simpler illustration of this implicit or habitual knowing is what we have already encountered as the main guiding thread of this study: perceptual activity as necessarily guided by unwitting abductive inferential habits. On this level, the properly bodily roots of habits emerge; and even though Peirce is far from clear or univocal as other authors on the role of the body in shaping human cognition, his semiotic understanding of the habit does offer a link between those two meanings of "embodiment" - a stricter and a more metaphorical one - that many authors, among them Edgar Wind, regard as belonging together.

62 At the same time, Peirce's account of perception also plays an important role in his vindication of pragmatism. Precisely the symbolische Prägnanz of perception (to borrow Cassirer's expression) ${ }^{102}$ makes available the rationality or legality embedded in the material world. Indeed, it is this rational dimension (laws of nature, to begin with), and not brute materiality, which is most real, and to which our cognition primarily attends somewhat akin to the way, on a different scale, "we can repeat the sense of a conversation but not the words uttered." 103

We face here two sides of the same coin. Both the secondness-related aspects of reality and our habitual inferential apparatus are things we draw upon in the processes of forming our perceptual judgments (and hence the whole spectrum of our conceptions). These are abductive processes, abduction being the only mode of inference able to bring about new cognitions, by springing from the particular - the hic et nunc - to the universal. 
Peirce also called pragmatism "the logic of abduction": it is via abductive processes that the world of material existence immediately surrounding us acquires its rational and understandable nature. From this angle, his account of reasoning reveals indeed its vicinity to those broadly coeval thinkers who, sensitive to the cognitive value of the particular, as well as to the unwitting, tacit and mediating dimension of human agency, were on the lookout for a more flexible, craft-made, and less strictly analytical notion of rationality: more akin to the model of medicine than to mathematics. ${ }^{104}$ "subjective," "interpretative," "synthetic," "intuitive," "diagnostic character of iconological analysis ${ }^{105}$ are all half-successful attempts to come to grips with the epistemological challenges lurking within his own method. Karl Mannheim's more rigorous notion of Dokumentsinn, which Panofsky drew upon so heavily, belongs to the same context. In both cases, these thinkers draw attention not so much to the abductive process carried out by the subject, but rather to the complementary one which the beholder, or interlocutor, has to perform in order to pass from the concrete particular to the general interpretant that governs it. As in every instance of communication, which always presupposes a duality, two different subjectivities or conceptual horizons confront each other and interact here. The hermeneutic circularities that Wind and Panofsky detect in every kind of inquiry (and which Peirce, similarly though less explicitly, touches upon in his account of abduction) more decisively leap to the foreground.

\section{BIBLIOGRAPHY}

ABELS H., (1994), “Die Zeit wieder in Gang bringen. Soziologische Anmerkungen zu einer unterstellten Wirkungsgeschichte der Ikonologie von Erwin Panofsky," in B. Rudenbach (ed.), Erwin Panofsky. Beiträge des Symposions. Hamburg 1992, Berlin, Akademie Verlag.

AQUINAS Th., (1964-73), Summa Theologiae [1265-1274], ed. by Thomas Gilby et al., Cambridge/New York, Blackfriars/McGraw Hill.

ARGAN G. C., (1975), “Iconology and Ideology,” Critical Inquiry, 2 (2), 297-305.

ARISTOTLE, (1957), On the Soul. Parva Naturalia. On Breath, transl. by W. S. Hett, Cambridge (Mass.)/ London, Harvard University Press.

ARrouYe J., (1983), “Archéologie de l'iconologie,” in Erwin Panofsky, Paris, Centre George Pompidou et Pandora Éditions.

BAXANDALL M., (1972), Painting and Experience in Fifteenth Century Italy, Oxford/New York, Oxford University Press.

BENVENISTE É., (1974), “Sémiologie de la langue” [1969], in Id., Problèmes de linguistique générale, II, Paris, Gallimard.

BERGMAN M., (2007), "Representationism and Presentationism," Transactions of the Charles S. Peirce Society, 43 (1), 53-89. 
BERNSTEIN R. J., (1964), “Peirce's Theory of Perception," in E. C. More, R. S. Robin (eds.), Studies in the Philosophy of Charles S. Peirce, Second Series, Amherst, University of Massachusetts Press.

BLUNT A., (1938), "Blake's ‘Ancient of Days': The Symbolism of the Compasses," Journal of the Warburg Institute, 2 (1), 53-63.

BOURDIEU P. (ed.) (1965), Un art moyen. Essai sur les usages sociaux de la photographie, Paris, Les Éditions de Minuit.

BOURDIEU P., (1966), “Champ intellectuel et projet créateur,” Les Temps Modernes, 22 (246), 865-906.

BouRdieu P., (1967), “Postface," in E. Panofsky, Architecture Gothique et Pensée Scolastique, transl. by P. Bourdieu, Paris, Éditions de Minuit.

BOURDIEU P., (1968), “Éléments d'une théorie sociologique de la perception artistique," Revue internationale des sciences sociales, 20 (40), 640-64.

BOURDIEU P., (1969), "Intellectual Field and Creative Project," transl. by S. France, Social Science Information, 8, 2, 89-119.

BOURDIEU P., (1970), "La maison kabyle ou le monde renversé," in J. Pouillon \& P. Maranda (eds.), Échanges et communications. Mélanges offerts à Claude Lévi-Strauss à l'occasion de son 60e anniversaire, Paris/The Hague, Mouton.

BOURDIEU P., (1971), “Disposition esthétique et compétence artistique," Les Temps Modernes, 27, 295, 1345-78.

BOURDIEU P., (1972), Esquisse d'une théorie de la pratique, précédé de trois études d'ethnologie kabyle, Genève, Librairie Droz.

BOURDIEU P., (1985), “The Genesis of the Concepts of Habitus and Field," transl. by Ch. Newman, Sociocriticism 2, 11-24.

BOURDIEU P. (ed.), (1990), Photography. A Middle-brow Art, Cambridge (UK), Polity Press.

BOURDIEU P., (1992), Les règles de l'art. Genèse et structure du champ littéraire, Paris, Éditions du Seuil. BOURDIEU P., CHAMBOREDON J.-C. \& J.-C. PASSERON, (1968), Le métier de sociologue. Préalables épistémologiques, Paris/La Haye, Mouton.

BREDEKAMP H., (1995), "Words, Images, Ellipses," in I. Lavin (ed.), Meaning in the Visual Arts: Views from the Outside. A Centennial Commemoration of Erwin Panofsky (1892-1968), Princeton, Institute for Advanced Studies.

BRENT J., (1993), Charles S. Peirce: A Life, Bloomington, Indiana University Press.

BUSCHENDORF B., (2001), "Das Prinzip der inneren Grenzsetzung und seine methodologische Bedeutung für die Kulturwissenschaften," Nachwort, in Wind 2001.

CAMIC C., (1986), “The Matter of Habit,” The American Journal of Sociology, 91 (5), 1039-87.

CAMIC C., (2001), "Habit. History of a Concept," in N. J. Smeler \& P. B. Baltes (eds.), International Encyclopedia of the Social and Behavioral Sciences, Amsterdam/New York, Elsevier.

DE TIENNE A., (1996), L'analytique de la représentation chez Peirce. La genèse de la théorie des catégories, Bruxelles, Facultés universitaires Saint-Louis.

DYNES W., (1973), “Concept of Gothic," in P. P. Wieney (ed.), Dictionary of the History of Ideas, vol. 2., New York, Charles Scribner's Sons. 
ENGEL F., (2012), "In einem sehr geläuterten Sinne sind sie doch eigentlich ein Empirist!" Ernst Cassirer und Edgar Wind im Streit über die Verkörperung von Symbolen," in U. Feist \& M. Rath (eds.), Et in imagine ego. Facetten von Bildakt und Verkörperung, Berlin, Akademie Verlag.

FALKENBURG B., (2001), “Die Maßsetzung im Endlichen,” Einleitung, in Wind 2001.

FISCH M. H., (1967), “Peirce's Progress from Nominalism toward Realism," in Id., Peirce, Semeiotic, and Pragmatism, Bloomington, Indiana University Press, 1986.

FRANKL P., (1960), The Gothic. Literary Sources and Interpretations through Eight Centuries, Princeton, Princeton University Press.

FUNKE G., (1961), Gewohnheit [1958], Archiv für Begriffsgeschichte, 3, Bonn, H. Bouvier \& Co.

GINZBURG C., (2000), “Spie. Radici di un paradigma indiziario" [1979], in Id., Miti emblemi spie. Morfologia e storia, third edition, Torino, Einaudi.

Gombrich E. H., (1969), In Search of Cultural History. The Philip Maurice Deneke Lecture 1967, Oxford, Clarendon Press.

GRUPO DE ESTUDIOS PEIRCEANOS, (2008-2012), “Correspondencia Europea de C. S. Peirce: creatividad y cooperación cientifica," [unav.es/ gep/CorrespondenciaEuropeaCSP.html] (last consulted April 2012).

HANKS W. F., (2005), "Pierre Bourdieu and the Practices of Language," Annual Review of Anthropology 34, 67-83.

HART J., (1993), “Panofsky and Karl Mannheim: A Dialogue on Interpretation," Critical Inquiry, 19 (3), 534-66.

HECKSCHER W. S., (1995), “Erwin Panofsky: A Curriulum Vitae, Hannover, 30 March 1892 Princeton, 14 March 1968," in E. Panofsky, Three Essays on Style, Cambridge (Mass.)/London, MIT Press.

HOLLY M. A., (1984), Panofsky and the Foundations of Art History, Ithaca/London, Cornell University Press.

ноок S., (1927), The Metaphysics of Pragmatism, with an introductory word by John Dewey, Chicago/London, Open Court.

JOAS H., (1992), Pragmatismus und Gesellschaftstheorie, Frankfurt a. M., Suhrkamp.

KANT I., (1905 [1764]), "Beobachtungen über das Gefühl des Schönen und Erhabenen," in Kants Gesammelte Schriften, hg. von der königlich Preußischen Akademie der Wissenschaften, Bd. 2, Berlin, Georg Reimer.

KETNER K. L., (1998), His Glassy Essence. An Autobiography of Charles S. Peirce, Nashville/London, Vanderbilt University Press.

KROIS J. M., (1998), “Kunst und Wissenschaft in Edgar Winds Philosophie der Verkörperung," in H. Bredekamp et al. (eds.), Edgar Wind Kunsthistoriker und Philosoph, Berlin, Akademie Verlag.

KROIS J. M., (2004), “More than a Linguistic Turn in Philosophy: The Semiotic Programs of Peirce and Cassirer," Sats - Nordic Journal of Philosophy, 5 (2), 14-33.

KROIS J. M., (2008), “Cassirer's ‘Symbolic Values' and Philosophical Iconology,” Cassirer Studies 1. MANNHEIM K., (1964 [1923]), “Beiträge zur Theorie der Weltanschauungs-Interpretation," in Id., Wissenssoziologie. Auswahl aus dem Werk, ed. by K. H. Wolff, Berlin/Neuwied, Luchterhand. 
MAUSS M., (2010), Les techniques du corps [1934], in Id., Sociologie et anthropologie, twelfth edition, Paris, PUF.

MOoRE J. A., (1984), “The Semiotic of Bishop Berkeley - A Prelude to Peirce?,” Transactions of the Charles S. Peirce Society, 20 (3), 325-42.

NAGEL E., (1934), Review of E. Wind, Das Experiment und die Metaphysik (Tübingen 1934), The Journal of Philosophy, 31 (6), 164-65.

NUBIOLA J., (2009), “29 enero - 30 enero 1871 (C. S. Peirce y Zina Fay, MS 1614, p. 12,” translation and commentary of Peirce's letter, [unav.es/gep/Agenda29-30Enero.html] (last consulted April 2012).

nUbiola J. \& S. BARRENA, (2009), “Charles Peirce's First Visit to Europe, 1870-71: Scientific Cooperation and Artistic Creativity," European Journal of Pragmatism and American Philosophy, 1 (1). OEHLER K., (1982), “Notes on the Reception of American Pragmatism in Germany, 1899-1952," Transactions of the Charles S. Peirce Society, 17 (1), 25-35.

PANOFSKY E., (1955), Meaning in the Visual Arts: Papers in and on Art History, Garden City, Doubleday. PANOFSKY E., (1957 [1951]), Gothic Architecture and Scholasticism: An Inquiry into the Analogy of the Arts, Philosophy, and Religion in the Middle Ages, New York, Meridian.

PANOFSKY E., (1969), "Erasmus and the Visual Arts," Journal of the Warburg and Courtauld Institutes $32,220-7$.

PANOFSKY E., (1972 [1939]), Studies in Iconology: Humanistic Themes in the Art of the Renaissance, reprint: New York, Harper \& Row.

PANOFSKY E., (1998), Deutschsprachige Aufsätze, 2 vol., ed. by K. Michels \& M. Warnke, Berlin, Akademie Verlag (Studien aus dem Warburg-Haus).

PANOFSKY E., (2001-11), Korrespondenz 1910 bis 1968. Eine kommentierte Auswahl in fünf Bänden, 5 vol., ed. by D. Wuttke, Wiesbaden, Harrassowitz Verlag.

PEIRCE Ch. S., (1923), Chance, Love, and Logic. Philosophical Essays, ed. and introduced by M. R. Cohen, with an essay by John Dewey, New York, Harcourt, Brace \& Co.

PEIRCE Ch. S., (1931-58), [CP] Collected Papers of Charles S. Peirce, 8 vol., vol. 1-6 ed. by Ch. Harsthorne and P. Weiss; vol. 7-8 ed. by A. W. Burks, Cambridge (Mass.), The Belknap Press of the Harvard University Press.

PEIRCE Ch. S., (1975-87), [CN] Charles Sanders Peirce: Contributions to the Nation, 4 vol., ed. by K. L. Ketner and J. E. Cook, Lubbock, Texas Tech Press.

PEIRCE Ch. S., (1982-), [W] Writings of Charles S. Peirce. A Chronological Edition, ed. by Peirce Edition Project, Bloomington, Indiana University Press.

PEIRCE Ch. S., (1985), [HP] Historical Perspectives on Peirce's Logic of Science. A History of Science, 2 voll., ed. by C. Eisele, Berlin/New York/Amsterdam, Mouton.

PEIRCE Ch. S., (1992), [RLT] Reasoning and the Logic of Things. The Cambridge Conferences Lectures of 1898, ed. by K. L. Ketner, Cambridge (Mass.)/London, Harvard University Press.

PEIRCE Ch. S., (1992-98), [EP] The Essential Peirce: Selected Philosophical Writings, 2 voll.; vol. 1 ed. by N. Houser \& Ch. Kloesel; vol. 2 ed. by Peirce Edition Project, Bloomington/Indianapolis, Indiana University Press.

PEVSNER N., (1942), “The Term 'Architect' in the Middle Ages," Speculum, 17 (4), 549-62. 
PODRo M., (1982), The Critical Historians of Art, New Haven/London, Yale University Press. POLANYI M., (2009 [1966]), The Tacit Dimension, Chicago/London, The University of Chicago Press. RAAB J., (2007), “Die 'Objektivität' des Sehens als wissenssoziologisches Problem,” Sozialersinn, 8 (2), 287-304.

RECHT R., (2008), “L'historien de l'art est-il naïf? Remarques sur l'actualité de Panofsky," in Relire Panofsky, Paris, Beaux-arts de Paris.

Rollins M., (1998), “Picture Perception,” in M. Kelly (ed.), Encyclopedia of Aesthetics, New York, Oxford University Press.

SCHAPIRO M., (1999), "Philosophy and Worldview in Painting [1958-68]," in Id., Worldview in Painting - Art and Society. Selected Papers, New York, George Braziller.

SCHWARTZ R., (1994), Vision. Variations on Some Berkeleian Themes, Oxford/Cambridge Mass., Blackwell.

STERN R., (2005), “Peirce on Hegel: Nominalist or Realist?,” Transactions of the Charles S. Peirce Society, 41 (1), 65-99.

STERN R., (2007), “Peirce, Hegel, and the Category of Secondness," Inquiry, 50 (2), 123-55.

StJernfelt F., (2002), "Symbol and Schema in Neo-Kantian Semiotics - The Philosophies of Cassirer and Peirce: Contributions to a Semiotics Implying an Epistemology," in G. Foss \& E. Kasa (eds.), Forms of Knowledge and Sensibility: Ernst Cassirer and the Human Sciences, Kristiansand, Norwegian University Press.

WHEWELL W., (1840), Philosophy of the Inductive Sciences: Founded Upon their History, London, John W. Parker.

WHEWELL W., (1842 [1830, 1835²]), Architectural Notes on German Churches; with Notes Written during an Architectural Tour in Picardy and Normandy. The Third Edition, to which are added Notes on the Churches of the Rhine, by M. F. de Lassaulx, Cambridge, J. and J. J. Deighton.

WHEWELL W., (1857 [1837, 1846²]), History of Inductive Sciences from the Earliest to the Present Time, Third edition, London, John W. Parker.

WIND E., (1927), "Experiment and Metaphysics," in E. S. Brightman (ed.), Proceedings of the Sixth International Congress of Philosophy, Harvard University, ... 1926, New York, Longmans.

WIND E., (1932), "Mathematik und Sinnesempfindung. Materialien zu einer Whitehead-Kritik," Logos, Internationale Zeitschrift für Philosophie der Kultur 21, 239-80.

WIND E., (1934), “Can the Antinomies Be Restated?," Psyche 14, 177-78.

WIND E., (1936), "Some Points of Contact between History and Natural Science," in R. Klibansky \& H. R. Paton (eds.), Philosophy and History. Essays Presented to Ernst Cassirer, Oxford, Clarendon Press. WIND E., (1949), "Mantegna's Parnassus: A Reply to Some Recent Reflections," The Art Bulletin, 31 (3), 224-31.

WIND E., (1954), Wissenschaft und Freiheit, Internationale Tagung, Hamburg, 23.-26. Juli 1953, Berlin, Grunewald Verlag, 280-1.

WIND E., (1958), “Microcosm and Memory,” Times Literary Supplement, 30 May, 297.

WIND E., (1985 [1960]), Art and Anarchy, third edition, London, Duckworth. 
WIND E., (1988), “Über einige Berührungspunkte zwischen Naturwissenschaft und Geschichte," in Wissenschaft. Zum Verständnis eines Begriffs, Köln, Rudolf Müller, 34-39; reprinted in Wind 2001, and 2009.

Wind E., (2000), The Religious Symbolism of Michelangelo: The Sistine Ceiling, Oxford, Oxford University Press.

WIND E., (2001 [1934]), Das Experiment und die Metaphysik. Zur Auflösung der kosmologischen Antinomien, Frankfurt, Suhrkamp.

WIND E., (2009), Heilige Furcht und andere Schriften zum Verhältnis von Kunst und Philosophie, ed. by J. M. Krois \& R. Ohrt, Hamburg, Philo Fine Arts.

WIND E., (2011), Ästhetischer und kunstwissenschaftlicher Gegenstand. Ein Beitrag zur Methodologie der Kunstgeschichte, ed. by P. Schneider, Hamburg, Philo Fine Arts.

WILLIS R., (1845), Architectural History of Canterbury Cathedral, London, Longman.

WÖLLFLIN H., (1888), Renaissance und Barock. Eine Untersuchung über Wesen und Entstehung des Barockstils in Italien, München, Theodor Ackermann.

\section{NOTES}

1. "Issues of Pragmaticism" (1905), EP 2: 349n. See further, par. VIII.

2. Camic 1986, 2001; Funke 1961. See in particular Mauss 2010: “J'ai [...] eu pendant de nombreuses années cette notion de la nature sociale de l"habitus.' [...] Le mot traduit, infiniment mieux qu'habitude,' l'hexis,' l"acquis' et la 'faculté' d'Aristote [...]."

3. See Bourdieu 1970.

4. Bourdieu 1967. See also Bourdieu 1985, Hanks 2005, Raab 2007.

5. Bourdieu, Chamboredon \& Passeron (1968: 92, 97-98, 287-9, 324-7). Wind's sentence is translated as follows: "Peirce écrit dans un fragment sur la psychologie du développement des idées: 'ce qu'il nous faut étudier ce sont le croyances que les hommes nous livrent inconsciemment, et non pas celles dont ils font étalage'."

6. Bourdieu (1969: 118; emphases mine). The original French version, Bourdieu (1966: 905), reads: “rapporter les œuvres d'une époque aux pratiques de l'école c'est donc se donner un des moyens d'expliquer non seulement ce qu'elles proclament, mais aussi ce qu'elles trahissent en tant qu'elles participent de la symbolique d'une époque ou d'une société." See also Bourdieu (1965: 23-4): “Comprendre adéquatement une photographie [...] ce n'est pas seulement reprendre les significations qu'elle proclame, c'est-à-dire, dans une certaine mesure, les intentions explicites de son auteur, c'est aussi déchiffrer le surplus de signification qu'elle trahit en tant qu'elle participe de la symbolique d'une époque, d'une classe ou d'un groupe artistique." The second edition of this text (see the English translation, Bourdieu 1990) is particularly interesting, for there Bourdieu introduced the notion of habitus as the solution for that "mediation between the subjective and the objective" which the first edition was still seeking in the concepts of "alienation, attitude or ethos," or even in "class consciousness" (Bourdieu 1965: 20-2).

7. Bourdieu 1972.

8. Bourdieu (1992: 432ff.).

9. Benveniste (1974: 61); Argan (1975) calls Panofsky "the Saussure of art history." See also Holly (1984: 43ff., 181-3) and Horst Bredekamp's misgivings (1995). Benveniste was an important figure for Bourdieu: he often quoted the former's linguistic works, and precisely in 1969 published Les vocabulaires des institutions indo-européennes in his book series Le sens commun. Benveniste, for his part, in his pages on Panofsky quoted both Bourdieu's translation and his postface. 
10. See Abels 1994, and Arrouye 1984.

11. Joas 1992 has been a fundamental inspiration for this study. I am aware that arguing for the existence of such a link between pragmatism and Bourdieu's sociology may sound problematic to readers acquainted with the critique Luc Boltanski addressed to his former teacher, from a standpoint he explicitly relates to American pragmatism. Of course, the topic goes beyond the scope of this article, and I plan on dealing with it more thoroughly in the future; but let me just say that what is normally referred to as "pragmatism" is vague and heterogeneous enough to accommodate the apparent contradiction. (I thank Séverine Marguin for having first alerted me to this problem.)

12. Kant (1905: 255-6). See Schapiro 1999.

13. I am relying here and elsewhere on Frankl (1960, see 487-8, 591-2 and passim). See also Gombrich (1969, especially 28). Wölfflin's words (1888: 62) are particularly revealing: once the need for a bridge between art and the "Inhalt der Zeit" is assumed on a general level, he says, "welches soll der Weg sein, der von der Zelle des scholastischen Philosophen in die Bauhütte des Architekten führt?"

14. Frankl (1960: 228). See also Dynes 1973. From this angle, Kant's observation appears as the continuation of the tendency, already well established, to explore the parallels among different "Gothic" phenomena.

15. Cf. "A Guess at the Riddle" (1888), W 6: 168; "The Architecture of Theories" (1890), W 8: 98-110. On Arisbe see Brent (1993: 185-92).

16. Pevsner (1942: 559-62), and Frankl (1960: 135-6), who adds that Thomas' argument "does not support the thesis that scholasticism and Gothic are related [...] On the other hand, it does support the thesis that around 1260 the workmaster or architect was looked upon as a man who had duties on the building site comparable to those of the philosopher in the university lecture hall."

17. See Fisch 1967.

18. $W 2$ : $467-71$.

19. $W$ 2: 485.

20. De Anima, 417a22 ff. See also Peirce's "Upon Logical Comprehension and Extension" (1867), $W$ 2: 75.

21. $W$ 2: 472.

22. "Issues of Pragmaticism" (1905), CP 5.441: "since we are conscious of what we do deliberately, we are conscious habitualiter of whatever hides in the depths of our nature; and it is presumable [...] that a sufficiently energetic effort of attention would bring it out." See also CP 5.504, c. 1905.

23. $W$ 2: 479-81.

24. CN 3: 36 (1901). See also $W$ 2: 483, where Berkeley's recurring argument "that such and such a thing cannot exist because we cannot so much as frame the idea of such a thing" gets replaced by a rough version of the pragmatic maxim: "Do things fulfil the same function practically? Then let them be signified by the same word. Do they not? Then let them be distinguished."

25. Charles S. Peirce Papers, Houghton Library, Harvard University, Cambridge, Mass. [MS], L231. See Moore 1984. The other name continuously cited as a direct source of pragmatism is of course Kant.

26. See, e.g., Schwartz 1994.

27. See Bernstein 1964, Bergman 2007.

28. $W$ 2: 166; 196 ("There can be no doubt that before the publication of Berkeley's book on Vision, it had generally been believed that the third dimension of space was immediately intuited, although, at present, nearly all admit that it is known by inference."); 233-6 (all from 1868). But see also, much later, CP 7.624 (1903): "Since 1709, [psychologists] have been in possession of sufficient proof [...] that, notwithstanding its apparent primitiveness, every percept is the product of mental processes, or at all events of processes for all intent and purposes 
mental, except that we are not directly aware of them; and these are processes of no little complexity." The importance of Berkeley's theory of vision is also much emphasized in the already mentioned 1901 review: $C N$ 3: 36-39.

29. $W$ 2: 463-4.

30. $W$ 2: 464-5. Let me cursorily draw the attention to the phrase "tone of thought," which is far from innocent, for in Peirce's technical vocabulary it designs the firstness of thirdness, or the quality of a sign. A scholastic commentary is a semiotic entity embodying a quality that can be put in relation to that of different semiotic phenomena - like cathedrals.

31. $W$ 2: 465-7.

32. See Brent (1993: 79-81); Nubiola \& Barrena 2009.

33. The letters, addressed to Peirce's close relatives, are contained in MS L129, L333, L336, L337, L339, L341. They also contain some interesting drawings. In addition to these, I am taking into account MS 1614 (a personal diary) and MS 1560a (a list of suggestions for a friend's subsequent visit to Europe). As of 2007, all this material has been published online, together with a commentary and many other related documents, by the Grupo de Estudios Peirceanos of the University of Navarra, Spain, under the direction of Jaime Nubiola: See Grupo de Estudios Peirceanos 2008-2012; Nubiola, Barrena 2009.

34. Peirce to his family, Apr. 14th, 1875, MS L341.

35. From the numerous churches Peirce visited, one may mention Netley Abbey ("if you go to Southampton don't omit Netley Abbey," MS 1560a), Salisbury Cathedral (described as superior to St. Peter's, Peirce to Sarah Mills, 14 Oct. 1870, MS L341), Milan cathedral ("wondrous," MS 1614), as well as many other buildings in Switzerland and Germany as those Peirce seemed to enjoy more.

36. I take the information from Nubiola's commentary of Peirce's diary, Nubiola 2009, which in turn relies on a file by Max H. Fisch conserved in the Peirce Edition Project archives in Indianapolis. Fisch says that the book (annotated by Peirce) was conserved with the Peirce papers; yet it has been impossible to locate it. Frankl (1960: 530) finds the importance of Willis' treatise "in its being the first detailed monograph in the modern sense, with a complete analysis of all parts of the structure and reconstructions of the state of the work at various times."

37. MS 1614.

38. Whewell 1842. Peirce is likely to have known of Robert Willis precisely through this book, the third edition of which was issued under the stimulus of the latter's objections (see preface).

39. $W$ 2: 486.

40. $W 1: 211$ (1865).

41. Whewell (1840: xvii); W 1: 205.

42. $W$ 2: 344 (1869).

43. $W$ 2: 338-9. See in particular the introduction of Whewell 1857. Cf. also, much later, MS 1274a (c. 1892). It is also interesting to note that Whewell's Architectural Notes are already mentioned in passing in $W 2: 338$.

44. Whewell 1857 , book IV, and particularly p. $246 \mathrm{ff}$.

45. $W$ 8: 203-4. It is interesting to note Peirce's reference to "extant documents" showing "that the cathedral chapters, in the selection of architects, treated high artistic genius as a secondary consideration."

46. HP 1: 143-4: "The celebrated scientific philosopher, William Whewell, published [...] a truly great book, the History of the Inductive Sciences, followed by another three years later called the Philosophy of the Inductive Sciences founded upon their history. Mill's Logic was chiefly written to disprove Whewell's theory of the Inductive sciences; but Whewell's book is distinguished for its truth to history while Mills [sic] is distinguished for bumping up against the facts of history at every turn like an awkward and overconfident walzer. [...] [A] new book in the general spirit of Whewell's is called for." 
47. HP 1: 350-35, emphases mine. See also Peirce's letter to Zina Fay from Hellespont, Sept. 4th, 1870: "Saint Sophia is fine but the style of it is altogether below the Gothic \& I thought the Saracenic style of architecture rather poor in ideas" (MS L337).

48. A draft contained in the correspondence files with American artist Francis Lathrop is a third example of Peirce's confrontation with the issue: see MS L245 (c. 1901). Peirce here compares the history of medieval logic with that of architecture, both in the importance of the birth of a new "style" and in the way they were eventually brought to an end.

49. Panofsky (1955: 30)

50. Panofsky (1957: 1-20). In a way that recalls Peirce's critique of Berkeley as both a nominalist and a Platonist, Panofsky construed Ockhamism and fourteenth-century mysticism as two sides of the same subjectivist trend that widened the gap between reality and rationality (or between reason and faith), and allotted a primacy to intuitus and private experience.

51. Panofsky (1957: 21ff.)

52. Aquinas (1964-73, I-II, 49, 3).

53. Panofsky $(1957: 37-8,99)$. The primary reference is to Rudolf Arhneim. It is worth noting that while Panofsky considered this theory of perception as "very much in harmony" with Scholasticism, he said it is "in contrast to the doctrine of the nineteenth century." On the coexistence of differences and analogies between Gestalt psychology and the Berkeley-Helmholtz tradition one may consult Rollins 1998.

54. Aquinas (1964-73), Ia, 5, 4. "Ratio" may alternatively be translated as "proportion." See Aristotle, De Anima, 426b4.

55. "Das Problem des Stils in der bildenden Kunst" (1915), in Panofsky (1998: 1009-18). See also Holly (1984: 57-68).

56. "Der Begriff des Kunstwollens" (1920), in Panofsky (1998: 1019-34).

57. Die Perspektive als symbolische Form (1924-25), in Panofsky (1998: 664-757).

58. "Über das Verhältnis der Kunstgeschichte zur Kunsttheorie. Ein Beitrag zu der Erörterung über die Möglichkeit, kunstwissenschaftlicher Grundbegriffe" (1924), in Panofsky (1998: 1035-63). On the roots of Panofky's conception of "artistic problems," which is of course strongly (and explicitly) dependent on Riegl and Wölfflin, cf. also Podro (1982: 33-7). On Wind see further, par. VII.

59. Mannheim 1964. The word "Habitus" is on 109; Panofsky is quoted on 123n, 128n, 140n. On Panofsky and Mannheim cf. Hart 1993; Recht (2008: 22).

60. Panofsky (1998: 1058n28).

61. (Ibid.: 178-85).

62. (Ibid.: 176-7).

63. (Ibid.: 264, 449, 982, 988).

64. Panofsky to Th. W. Koch, Aug. 24th, 1938; Panofsky (2001-11, 2: 135). Cf. also (ibid., 172). In 1939 Panofsky had not yet drawn the distinction between "iconography" and "iconology": the first term covered the whole spectrum of meanings.

65. Panofsky (2001-11, 2: 714).

66. Cf., e.g., Panofsky (2001-11, 2: 514-5, 1037). Cf. also Heckscher (1995: 184): "I know that Panofsky passionately believed in the theses of Gothic Architecture and Scholasticism. This works highlights, it seems to me, the specifically scholastic strain in his whole manner of thinking. He felt vulnerable in publishing this confessio amantis, more so than ever before or after." Panofsky held also a very interesting exchange on the content of this books with M. Shapiro, E. Curtius, E. Auerbach. Cf. Panofsky (2001-11, 3: 191-194, 199-202, 208, 212).

67. Panofsky (1998: 1064-77).

68. Panofsky (1955: 14). See also Panofsky (1969: 204) and the letter to H. M. Kallen, May 8th, 1950: Panofsky (2001-11, 3: 25). 
69. Podro 1982 locates the roots of the German art-historical tradition leading to Panofsky in the work of Kant, Schiller and Hegel. On the first I have already commented. Schiller's Aesthetic Letters is described by Peirce as his "first dip into philosophy" (see Ketner (1998: 139), De Tienne (1996: 33-41)). On Peirce's troubled but important relation to Hegel see Stern 2005, 2007.

70. Krois 2004; Stjernfelt 2002.

71. Biographical informations on Wind are from Krois 1998.

72. Wind 2011, which also contains Panofsky's and Cassirer's Gutachten.

73. Cf. Wind 1927, 2001. These are the texts to which Panofsky referred in 1932.

74. Wind 1932. Neither Joas 1992 nor Oehler 1981 show awareness of this chapter in the German reception of Peirce.

75. Krois (1998: 184), originally a personal communication from Margaret Wind.

76. Hook 1927. Cf. also Krois 1998.

77. Hook (1927: 6). "The title of this study has been selected with malice prepense. It conjoins two terms whose connotations are generally regarded as opposite in order to make more emphatic the belief that 'method' is dogged by a pack of metaphysical consequences; that a 'pure' method which does not involve reference to a theory of existence is as devoid of meaning as a proposition which does not imply other propositions." Hook's interpretation of Blake's picture is criticized in Blunt 1938.

78. Cf. 11ff., and 29: "We use our eyes as we do our hands - to grope, to pry, to scan, to escape danger, to signal to a friend. Sense activity, like all behavior generally, is not inertly receptive [... ]. It is interactive. The eye is the organ of vision but the vision is not in the eye."

79. Nagel 1934.

80. Wind to Panofsky, Oct. 24, 1931, Panofsky (2001-11, 1: 410): "Morris Cohen (City College): kennen Sie schon etwas durch das Buch 'Nature and Reason' [i.e., Reason and Nature] das ich Ihnen in Hamburg zeigte. Sie werden ihn in jeder Hinsicht als sehr angenehm und klug empfinden."

81. Cf. The Journal of Philosophy, Psychology and Scientific Methods, 13, 26, 1916 (with contributions by Josiah Royce, John Dewey, Christine Ladd-Franklin, Joseph Jastrow, Morris R. Cohen). The anthology edited by Cohen is Peirce 1923.

82. Wind 1958.

83. For some parallels between Wind's thought and contemporary pragmatism cf. also Falkenburg 2001. Engel 2012 makes a similar point with regards to the differences between Wind and Cassirer.

84. I am drawing on Wind 1927, 1934, 1936, 1958, 2001. Buschendorf 2001 is a very useful overview of the main traits of Wind's philosophy.

85. Wind 1958 (emphasis mine).

86. See especially the 1934 "Einleitung" to the Kulturwissenschaftliche Bibliographie zum Nachleben der Antike, reprinted in Wind 2001 and 2009.

87. Wind (1934, 2001: 68).

88. EP 2:256 (1903).

89. EP 2: 269 (1903).

90. Wind (2001: 108).

91. "Warburgs Begriff der Kulturwissenschaft und seine Bedeutung für die Aesthetik" (1931), in Wind 2009. Cf. also Wind (1985: 22-3).

92. Wind 1985, fourth chapter. A similar case is made by Panofsky in "The History of Art as a Humanistic Discipline" (1940), in Panofsky 1955.

93. Wind (1936: 258)

94. The German original has been published posthumously: Wind 1988. Ironically, the volume in which the text appeared was part of a series on the relationship between architecture and science. The text is reprinted also in Wind 2001 and 2009. See Wind (2001: 254n) for informations 
on Wind's Probevorlesung. As I already mentioned, Panofsky quoted Peirce's sentence as early as 1932, that is, well before the publication of the Cassirer Festschrift.

95. See in particular the footnote on Wind (1988: 39n): "Schon zu Diltheys Zeiten war dieser Gedanke nicht neu. Vgl. Als ein Beispiel für viele, Carus, Psyche (1846). Auch soll bereits ähnliches gelehrt haben." The reference is to the German physiologist, polymath and painter Carl Gustav Carus (1789-1869). I thank Carlo Ginzburg for having made me aware of these differences between the English and the German texts.

96. See the article "On Small Differences of Sensation" which Peirce wrote together with his pupil Joseph Jastrow (W 5: 122-35, 1884). Not by accident Peirce also quoted this article in the very text of 1905 in which he dealt with the difference between betraying and parading as well as with Scotus' notion of being in the mind habitualiter (see fn. 23).

97. Wind 1954.

98. "Picture and Text," originally written for the introduction to Pagan Mysteries in the Renaissance , (1958), then discarded and published posthumously: Wind (2000: 191-3). The same passage (W 2: $213,1868)$ is quoted in Wind (1949: 231). On the opposition between "linear" and "configural," which is likely to come from Whitehead, cf. Wind (2011: 180-3).

99. EP 2: 349. (First emphasis mine.)

100. HP 1: 204 (1892), emphasis mine.

101. See Polanyi 2009.

102. Krois (2008: 115): “According to Cassirer, perception always already embodies various symbolic meanings simultaneously, and the majority of these meanings are not the result of intentional acts of interpretation. This thought clearly struck a responsive chord in Panofsky, who emphasizes the unintentional character of symbolical values in iconology."

103. EP 2: 229 (1903).

104. Ginzburg 2000.

105. Panofsky 1955.

\section{ABSTRACTS}

"[I]t is the belief men betray, and not that which they parade which has to be studied." This short Peircean sentence has been the subject of important yet underrated attention in the reception of Peirce's philosophy, passing through the art historians Edgar Wind and Erwin Panofsky and arriving finally at Bourdieu. This paper explores the affinities between Peirce's and Panofksy's thinking, as well as their historical connections and their common sources, taking its cue from an analysis of the similar arguments the two authors offer to justify the analogy between Gothic architecture and Scholasticism. The fulcrum for the comparison between Peirce and Panofsky is located in the writings of Edgar Wind: a leading figure, this article proposes, in the history of European pragmatism. 


\section{AUTHOR}

\section{TULLIO VIOLA}

Humboldt Universität zu Berlin

tullio.viola[at]gmail.com 